\title{
A comparative study of Olopatadine and Ketorolac eye drop with Ketorolac eye drop alone in seasonal allergic conjunctivitis
}

\author{
Meena R.K ${ }^{1}$, Gupta M.L ${ }^{2}$, Sharma H.P \\ ${ }^{1}$ Dr. Ravindra Kumar Meena, Assistant Professor, ${ }^{2}$ Dr. M. L. Gupta, Professor and HOD, ${ }^{3}$ Dr. H.P. Sharma, \\ Senior Resident, Department of Ophthalmology, Jhalawar Medical College (Raj.), India.
}

Address for Correspondence: Dr. Ravindra Kumar Meena, E-mail drravindrameena@gmail.com.

\begin{abstract}
Background: Seasonal allergic conjunctivitis is the most common allergic disorder seen in eyes. The aim of study was to compare the clinical efficacy of combination of $0.4 \%$ ketorolac and $0.1 \%$ olopatadine with $0.4 \%$ ketorolac alone in seasonal allergic conjunctivitis. Material and Method: The study was prospective, double blind parallel group comparative. Two hundred cases enrolled in the study. All the subjects were randomly divided in two groups, 100 in each. Group 1 patients received $0.4 \%$ ketorolac eye drop in both eyes 2 times a day and group 2 patients received combination of $0.1 \%$ olopatadine and $0.4 \%$ ketorolac in both eyes 2 times a day. Observations were collected at baseline and on day 3,7,15 and analyzed statistically regarding improvement in sign and symptoms. Result: In group 1, 50- 60\% patients had no sign and symptoms on day 15 whereas in group 2 more than 95\% patients showed improvement in clinical picture. p value was significant $(\mathrm{p}<0.0001)$ at day 15 in all sign and symptoms and on day 3 in itching and on day 7 in watering. Overall group 2 patients had better and earlier response regarding symptoms of itching at day 3. Conclusion: The combination of $0.1 \%$ olopatadine and $0.4 \%$ ketorolac was more effective than $0.4 \%$ ketorolac alone in seasonal allergic conjunctivitis patients.
\end{abstract}

Key words: Seasonal allergic conjunctivitis, Combination, Ketorolac, Olopatadine, Comparison

\section{Introduction}

Seasonal allergic conjunctivitis affects most of the people during their lifespan [1]. Main sign and symptom are itching, redness, watering and photophobia, some patients present with chemosis [1-6]. Severity of allergic conjunctivitis also depends upon allergen and immune system of the patient itself. It is the result of reaction between allergen and mast cell of our body [5,7,8,9]. Mast cells play very important role in pathogenesis of allergic conjunctivitis [10-14].

The best option to reduce its occurrence is to identify responsible substances for it and avoid its exposure but practically this thing is impossible [15]. Variety of drugs available in market for allergic conjunctivitis [2,16,17], but the drugs which have been used mostly are steroids but due to some adverse effects and serious complication

Manuscript received: $14^{\text {th }}$ August 2017

Reviewed: $23^{\text {rd }}$ August 2017

Author Corrected: $30^{\text {th }}$ August 2017

Accepted for Publication: $6^{\text {th }}$ September 2017 now a days we switch on some other non steroidal drugs like ketorolac, ketotifen, sodium chromoglycate, olopatadine etc. but in some severe cases these eye drops alone are not so effective in alleviating the sign and symptoms of seasonal allergic conjunctivitis.

So now the preparations which are coming in market are of combination of two or more molecules. Olopatadine have dual action mode as mast cell stabilizer and antihistaminic with safety profile, many studies have done on it [18-22].

Ketorolac is a NSAIDs which acts by inhibiting the prostaglandins and very effective in relieving the symptoms of itching.

In this study our aim was to compare the effectiveness of combination of $0.4 \%$ ketorolac and $0.1 \%$ Olopatadine eye drop with $0.4 \%$ Ketorolac alone in seasonal allergic conjunctivitis. 


\section{Material and Methods}

Study design: Prospective, randomized, doubleblind, single-centre, parallel group comparative study.

Setting: The study was conducted in the department of ophthalmology at Jhalawar medical college (raj.)

Inclusion criteria: All the Patients coming in the outpatient department with complaining of itching, redness, watering and photophobia were selected to participate in the study and diagnosed as a case of seasonal allergic conjunctivitis on the basis of sign (hyperemia) at slit lamp and symptoms (itching, watering, photophobia). No other methods of diagnosis were considered besides clinical signs and symptoms. For example, skin testing may have been useful to provide more accurate diagnosis but we chose to use signs and symptoms rather than skin testing mainly to reduce cost as the study was not externally funded.

Exclusion criteria: Patients were excluded if they had

1. Uveitis, conjunctivitis and other ocular pathology.

2. Bronchial asthma, eczema.

3. History of dry eye, blepharitis, using contact lens.

4. Receiving topical or systemic medication

5. History of sensitivity to any constituents of the eye drops.

Participants- 200 OPD patients diagnosed on the basis of sign and symptoms of allergic conjunctivitis were participated in the study.

Variables- The studied demographic variables included age, sex, rural, urban and occupation.

Questions pertaining severity of sign and symptoms of allergic conjunctivitis were asked. The study was conducted from April 2017 to June 2017 after obtaining permission from the ethical committee of our institute. This period was selected because most of the allergic patients came across during this period due to season of crop harvesting and change in temperature of atmosphere.

Data Source: The sign and symptoms of patients on clinical examination after scoring of these sign and symptoms.

Bias- No bias.

Study Size- 200 patients of allergic conjunctivitis.

Quantitative variables: No quantitative variables seen in our study.

Statistical Methods: Analysis was performed using chi-square test, p-value $<0.0001$ was considered significant

Methodology- After obtaining written informed consent and detail explanation of the study Patients who were found to be eligible according to selection criteria were recruited in to one of the treatment groups according to a stratified randomization list based on age and sex 100 patients in each.

Group 1(0.4\% ketorolac group) both eye of each of these patients received $0.4 \%$ ketorolac twice daily.

Group $2(0.4 \%$ ketorolac and $0.1 \%$ olopatadine combination group) received combination of $0.4 \%$ ketorolac and $0.1 \%$ olopatadine in both eye two times a day.

Detailed history and clinical examination were performed in a prescribed data collection form Study medications were provided in identical containers so that both patients and investigators were remained blinded. follow up was done at day $0,3,7,15$ regarding improvement in number of patients for Itching, Hyperemia, watering and photophobia by using four point scale method. During the study period if any patient complained regarding any side effect of eye drop we instruct them to contact immediately in OPD to chief investigator.

\section{Results}

Total 200 patients participated in this study. Data were collected and arranged in tables. Table no. 1 showed the demographic profile of patients, age, sex and occupation which showed that range of age was 18-50 years. Mean age of group1 patients was 30.24 where as in group 2 mean age was 33.52. Most of the patients in both groups 
are of male and by occupation they are field workers females those were affecting were of housewives. All these data showed no significant difference in between two groups.

Table No.-1: Scoring of sign and symptom of allergic conjunctivitis.

\begin{tabular}{|c|c|c|c|c|}
\hline \multirow{2}{*}{$\begin{array}{c}\text { Sign and } \\
\text { symptoms }\end{array}$} & \multicolumn{4}{|c|}{ Scoring of Sign and symptoms of allergic conjunctivitis } \\
\cline { 2 - 5 } & Score 0 (absent) & Score 1(mild) & Score 2 (moderate) & Score 3 (severe) \\
\hline Itching & Absent & occasionally & frequently & continuously \\
\hline Hyperemia & Absent & $\begin{array}{c}\text { Slightly dilated } \\
\text { blood vessels }\end{array}$ & $\begin{array}{c}\text { Moderate } \\
\text { vasodilatation }\end{array}$ & $\begin{array}{c}\text { Obviously dilated blood } \\
\text { vessels deep red in colour }\end{array}$ \\
\hline Watering & Absent & occasionally & frequently & Persistent \\
\hline Photophobia & Absent & occasionally & continuous & $\begin{array}{c}\text { Eye responds to } \\
\text { lepharospasm on exposure to } \\
\text { light }\end{array}$ \\
\hline
\end{tabular}

Table No.-2: Distribution of cases according to age and sex

\begin{tabular}{|c|c|c|}
\hline & Group 1 & Group 2 \\
\hline Mean age & 30.24 & 33.52 \\
\hline Male & 58 & 32 \\
\hline Female & 42 & 100 \\
\hline Total & 100 & 32 \\
\hline
\end{tabular}

Table No.-3: Scoring of itching on different day.

\begin{tabular}{|c|c|c|c|c|c|c|c|c|}
\hline & & 0 (none) & 1 (mild) & 2 (moderate) & 3(severe) & Total & $\begin{array}{c}\text { Chi } \\
\text { square }\end{array}$ & P value \\
\hline \multirow[t]{2}{*}{ Baseline } & Group1 & 00 & 20 & 40 & 40 & 100 & \multirow[t]{2}{*}{2.667} & \multirow[t]{2}{*}{0.2635} \\
\hline & Group2 & 00 & 30 & 35 & 35 & 100 & & \\
\hline \multirow[t]{2}{*}{ Day3 } & Group1 & 30 & 40 & 20 & 10 & 100 & \multirow[t]{2}{*}{18.333} & \multirow[t]{2}{*}{0.0003} \\
\hline & Group2 & 50 & 20 & 10 & 20 & 100 & & \\
\hline \multirow[t]{2}{*}{ Day 7} & Group1 & 40 & 45 & 10 & 05 & 100 & \multirow[t]{2}{*}{12.00} & \multirow[t]{2}{*}{0.0074} \\
\hline & Group2 & 60 & 30 & 10 & 00 & 100 & & \\
\hline \multirow[t]{2}{*}{ Day 15} & Group1 & 50 & 40 & 05 & 05 & 100 & \multirow[t]{2}{*}{51.188} & \multirow[t]{2}{*}{$<0.0001^{*}$} \\
\hline & Group2 & 95 & 05 & 00 & 00 & 100 & & \\
\hline
\end{tabular}

Table No.-4: Scoring of hyperemia on different day

\begin{tabular}{|c|c|c|c|c|c|c|c|c|}
\hline & & 0 (none) & 1 (mild) & 2 (moderate) & 3(severe) & Total & $\begin{array}{c}\text { Chi } \\
\text { square }\end{array}$ & $P$ value \\
\hline \multirow[t]{2}{*}{ Baseline } & Group1 & 00 & 15 & 45 & 40 & 100 & \multirow[t]{2}{*}{5.794} & \multirow[t]{2}{*}{0.0552} \\
\hline & Group2 & 00 & 25 & 30 & 45 & 100 & & \\
\hline \multirow[t]{2}{*}{ Day3 } & Group1 & 25 & 45 & 20 & 10 & 100 & \multirow[t]{2}{*}{26.408} & \multirow[t]{2}{*}{$<0.0001 *$} \\
\hline & Group2 & 60 & 20 & 15 & 05 & 100 & & \\
\hline \multirow[t]{2}{*}{ Day 7} & Group1 & 50 & 37 & 10 & 03 & 100 & \multirow[t]{2}{*}{9.559} & \multirow[t]{2}{*}{0.02271} \\
\hline & Group2 & 68 & 22 & 10 & 00 & 100 & & \\
\hline \multirow[t]{2}{*}{ Day 15} & Group1 & 60 & 30 & 08 & 02 & 100 & \multirow[t]{2}{*}{35.76} & \multirow[t]{2}{*}{$<0.0001 *$} \\
\hline & Group2 & 95 & 05 & 00 & 00 & 100 & & \\
\hline
\end{tabular}


Table No.-5: Scoring of Watering on different day.

\begin{tabular}{|c|c|c|c|c|c|c|c|c|}
\hline & & $\begin{array}{c}\mathbf{0} \\
\text { (none) }\end{array}$ & 1 (mild) & 2 (moderate) & 3(severe) & Total & chisquare & $P$ value \\
\hline \multirow[t]{2}{*}{ Baseline } & Group1 & 00 & 40 & 40 & 20 & 100 & \multirow[t]{2}{*}{5.853} & \multirow[t]{2}{*}{0.0536} \\
\hline & Group2 & 00 & 30 & 35 & 35 & 100 & & \\
\hline \multirow[t]{2}{*}{ Day3 } & Group1 & 30 & 40 & 15 & 15 & 100 & \multirow[t]{2}{*}{13.262} & \multirow[t]{2}{*}{$<0.0041$} \\
\hline & Group2 & 53 & 32 & 10 & 05 & 100 & & \\
\hline \multirow[t]{2}{*}{ Day 7} & Group1 & 38 & 42 & 08 & 12 & 100 & \multirow[t]{2}{*}{21.77} & \multirow[t]{2}{*}{$<0.0001 *$} \\
\hline & Group2 & 65 & 30 & 05 & 00 & 100 & & \\
\hline \multirow[t]{2}{*}{ Day 15} & Group1 & 50 & 42 & 05 & 03 & 100 & \multirow[t]{2}{*}{59.391} & \multirow[t]{2}{*}{$<0.0001^{*}$} \\
\hline & Group2 & 98 & 02 & 00 & 00 & 100 & & \\
\hline
\end{tabular}

Table No.-6: Scoring of photophobia on different day

\begin{tabular}{|c|c|c|c|c|c|c|c|c|}
\hline & & $\begin{array}{c}0 \\
\text { (none) }\end{array}$ & 1 (mild) & 2 (moderate) & 3(severe) & Total & chisquare & $P$ value \\
\hline \multirow[t]{2}{*}{ Baseline } & Group1 & 00 & 58 & 32 & 10 & 100 & \multirow[t]{2}{*}{0.098} & \multirow[t]{2}{*}{0.9522} \\
\hline & Group2 & 00 & 60 & 30 & 10 & 100 & & \\
\hline \multirow[t]{2}{*}{ Day3 } & Group1 & 38 & 43 & 15 & 04 & 100 & \multirow[t]{2}{*}{10.78} & \multirow[t]{2}{*}{0.0129} \\
\hline & Group2 & 58 & 32 & 10 & 00 & 100 & & \\
\hline \multirow[t]{2}{*}{ Day 7} & Group1 & 42 & 47 & 10 & 01 & 100 & \multirow[t]{2}{*}{11.364} & \multirow[t]{2}{*}{0.0099} \\
\hline & Group2 & 65 & 30 & 05 & 00 & 100 & & \\
\hline \multirow[t]{2}{*}{ Day 15} & Group1 & 53 & 44 & 01 & 02 & 100 & \multirow[t]{2}{*}{58.01} & \multirow[t]{2}{*}{$<0.0001^{*}$} \\
\hline & Group2 & 99 & 01 & 00 & 00 & 100 & & \\
\hline
\end{tabular}

Table no. 2 showed that in group 1 patients had improvement in itching on day 3 and 7 which is not so significant ( $p>0.0001)$ whereas group 2 patients had significant improvement at day $15(\mathrm{p}<0.0001)$.

Table no. 3 has data of hyperemia which reflect that group 1 patients also have good response in this sign although not significant

Table no. 4 depict that group 2 patients had better response in symptom of watering $(\mathrm{p}<0.0001)$

Table no. $5 \& 6$ also depict that group 2 patients had good results in comparison of group 1 if considering watering of eye and photophobia. $(\mathrm{p}<0.0001)$

\section{Discussion}

Allergic conjunctivitis is a common ocular problem. It is rarely associated with visionthreatening complication but can hamper the quality of life for patients due to its recurrent nature. To improve quality of life it is important to get early relief from signs and symptoms of allergic conjunctivitis. There are three types of simple allergic conjunctivitis acute, seasonal and perennial. Allergic conjunctivitis affects $10 \%$ to $30 \%$ of the general population [23]. In most of the cases younger age group patients suffers more in comparison to older people [24, 25]. The pathogenesis of allergic conjunctivitis is predominantly an IgE-mediated hypersensitivity reaction in which allergens interact with $\operatorname{IgE}$ bound to sensitized mast cells resulting in increased tear levels of histamine, tryptase, prostaglandins and leukotrienes [26,27].

The diagnosis is made clinically by taking history and ocular examination. Laboratory investigation is generally not required although skin prick test or serum allergy testing can be helpful identifying the offending allergens so that they can be avoided if possible. Variety of treatment available for allergic conjunctivitis very first we should educate the 
patients about general care of eye that they should not rub their eyes which causes worsening of symptoms. Advice them to use artificial tear and cool compresses frequently. When all these measure become fail pharmacologic treatment should applied topically to diminish the allergic response. The mainstay of the management of ocular allergy involves the use of anti-allergic therapeutic agents such as antihistamine, vasoconstrictor, and mast cell stabilizer. Topical antihistamines block histamine receptors and relieve itching and redness but only for a short time which necessitates frequent dosing of up to 4 times per day [28].

Combination of decongestants with antihistamines have been shown to be more effective and are administered to the eye as drops up to 4 times daily [29]. Decongestants are effective in reducing hyperemia but still side effects of burning and stinging on instillation, mydriasis, and rebound hyperemia with chronic use [29]. Therefore these drugs are suitable only for short period.

Mast cell stabilizer's mechanism is not clear. They may increase calcium influx into the cell which prevents changes in membrane or they may reduce membrane fluidity prior to mast cell degranulation which results in decrease of degranulation of mast cells, that prevents the release of histamine and other chemotactic factors which are present in the preformed and newly formed state. Mast cell stabilizers don't relieve existing symptoms and they can be used only for prophylaxis.

They require a loading period during which they must be applied before the antigen exposure. Therefore, poor compliance should be taken as a possible drawback of Mast cell stabilizers. In recent years many other drugs have been introduced with multiple anti-allergic action such as olopatadine, ketotifen, azelastine and epinastine that exert multiple anti allergic effects such as histamine receptor antagonist action, stabilization of mast-cell degranulation and suppression of activation and infiltration of eosinophils [30].

Olopatadine is a new topical ocular dibenzoxepin derivative [22]. It inhibits the release of preformed and newly synthesized inflammatory mediators from mast cells and also has antihistaminic properties towards $\mathrm{H} 1$ receptors. Its dual activity is an advantage and the drug may be used both as a therapeutic and prophylactic agent. The dual action also renders the drug superior in terms of clinical effectiveness, rapid onset and length of duration of action $[19,20]$.

Non-steroidal anti-inflammatory drug (NSAIDs) such as Ketorolac works through the inhibition of cyclooxygenase, which produces prostaglandins. Prostaglandin D2 is among the newly synthesized mediators released by mast cells following antigen stimulation, and inhibition of the production of this mediator can decrease the signs and symptoms of allergic conjunctivitis. It is used as additive drugs to reduce the conjunctival hyperemia and itching related to prostaglandin D2 and prostaglandin E2 [31].

Topical Corticosteroids also used in more severe variants of ocular allergy [32-36]. Corticosteroids possess immunosuppressive and anti-proliferative properties but they have some limitations like including elevated intraocular pressure, and formation of cataract. These agents are therefore appropriate for short courses (up to 2 weeks); however, if needed for longer durations, an eye examination should be carried out, including baseline assessment of cataracts and intraocular pressure measurement $[37,38]$.

In previous studies, olopatadine hydrochloride demonstrated significantly greater efficacy than placebo, mast cell stabilizers, NSAIDs and some other drugs Spangler et al.2001[48] Yaylali et al. 2003[39] Leonardi \& Zafirakis 2004[13].

We designed a single centre double-masked randomized trial, to compare the efficacy of combination of $0.4 \%$ ketorolac and $0.1 \%$ olopatadine with $0.4 \%$ ketorolac eye drop in allergic conjunctivitis patients.

Yaylali et al [39] conducted a study on 40 patients of allergic conjunctivitis, 21 were male and 19 were female. Their average age was 19 years (range 15-25 years). When the mean scores of olopatadine treated eyes were compared to the scores of ketorolac treated eyes, the mean scores of hyperemia were found to be lower in the olopatadine group, indicating better therapeutic effectiveness, although the difference did not reach statistical significance (p 0.154, 0.9, 0.65, 0.79, 
0.79 , for baseline, 30 minutes, 2,7 and 15 days scores, respectively) the results were favor of our study.

Chaudhary et al [44] conducted a study on 92 patients of allergic conjunctivitis out of which 42$45 \%$ are male patients mean age was $28 \pm 12$ and $28 \pm 11$ years. The baseline/pretreatment mean scores (SD) of hyperemia, tearing, itching and photophobia were $1.93 \pm 0.258,1.07 \pm 0.258,2.40$ \pm 0.495 and $1.35 \pm 0.573$, respectively, in the KF group. After 2 weeks of treatment with $0.025 \% \mathrm{KF}$ reduced the mean scores of hyperemia, tearing, itching and photophobia by $64,63,55$ and $81 \%$, respectively. On the other hand, the baseline mean scores (SD) of hyperemia, tearing, itching and photophobia were $1.90 \pm 0.304,1.13 \pm 0.607,2.45$ \pm 0.677 and $1.27 \pm 0.452$, respectively, in the OHCL group. After 2 weeks of treatment with $0.1 \%$ OHCL reduced the mean scores of hyperemia, tearing, itching and photophobia to 96 , 97,88 and $96 \%$, similarly in our mean age of group 1 patients was 30.24 where as in group 2 mean age was 33.52, group 2 patients mean score of itching, hyperemia watering and photophobia were $95,95,98,99 \%$ respectively which strongly prove that olopatadine in combination with ketorolac is very effective and safe.

We observed male predominance in both the groups (group $1 \quad 58 \%$,group $2 \quad 68 \%$ ) similar observation found in study of Pallasaho et al[40] where males were at higher risks for presenting allergic symptoms than females, Raukas- Kivioja et. Al [41] in their study demonstrated that the prevalence of allergic conjunctivitis was $34.50 \%$ and inversely related with the age.

Most of the patients in our trial are outdoor worker which gives the idea that allergic conjunctivitis was more in field worker especially young patients although could not prove statistically.

The mean scores for itching were found to be lower in the olopatadine and ketorolac group than in the ketorolac group in our study. At day 15, 95\% of patients had no copmplain of itching in group $2(\mathrm{p}$ value $<0.0001)$ table no.1 indicating that olopatadine and ketorolac in combination was superior to ketorolac in inhibiting ocular pruritus. The higher clinical effectiveness of olopatadine compared to ketorolac in alleviation of signs and symptoms allergic conjunctivitis, particularly of itching, may be explained by the dual action of this drug [3,19, 47-51].

According to Deschenes et al [47] Ketorolac, unlike olopatadine, does not inhibit mast cell degranulation and does not possess antihistamine activity. Although ketorolac inhibits pruritogenic prostaglandin synthesis, and thus has antipruritogenic effectivenessin the treatment of allergic conjunctivitis, the resultant anti-itching effect is less than that of olopatadine, which is a potent antihistaminic agent.

The authors explained ketorolac's lack of effectiveness in the inhibition of allergic response in the human conjuctiva on the basis that either prostaglandin D2, which is important in guinea pig allergic conjunctivitis, might have a limited role to play in human allergic conjunctivitis. But this explanation contradicts other studies which have clinically demonstrated the effectiveness of ketorolac in the treatment of allergic conjunctivitis patients $[43,45,46]$. In these studies ketorolac was used four times daily for 1 week, in a similar manner to our study we prescribed ketorolac two times a day

Katelaris et al (2002)[42] conducted a 6-week, multicenter, randomized controlled study to compare the effects of olopatadine hydrochloride $0.1 \%$ ophthalmic solution and disodium cromoglycate $2 \%$ ophthalmic solution on itching and hyperemia in 185 patients with allergic conjunctivitis which showed better efficacy for hyperemiathat results were also consistent with our study hyperemia score in group 2 reduced to $95 \%$. $\mathrm{p}<0.0001$ on day 3 and 15 group 1 patients have less response for hyperemia because ketorolac itself causes hyperemia on instillation.

Combination of olopatadine and ketorolac also showed effectiveness in reducing the watering and photophobia both the result of that are consistent with Deschenes et al. 1999 [47].

Overall the result of our study were in favor of combination of olopatadine and ketorolac eye drop use for allergic conjunctivitis as Castilo $\mathrm{M}$ etal [1] which also proved that olopatadine had summative role when given in combination with $0.4 \%$ ketorolac. 
Significant effectiveness was observed in reducing the signs and symptoms of itching, hyperemia and photophobia the reduction of photophobia was more than $46 \%$ higher in the group 2 than group 1 .

\section{Conclusion}

1. $0.1 \%$ Olopatadine and $0.4 \%$ Ketorolac eyedrop is more effective and safer than $0.4 \%$ Ketorolac alone in the management of seasonal allergic conjunctivitis.

2. Patients who received combination of olopatadine and ketorolac have faster recovery in hyperemia and itching without any side effect and thus this offers a promising new strategy for the management of allergic conjunctivitis.

3 . Frequency of dose is very less.

4. low cost of olopatadine and ketorolac in combination have improved patient Compliance.

5. Patients feel significantly less discomfort upon instillation.

So we can conclude that the combination of olopatadine $(0.1 \%)$ and ketorolac $(0.4 \%)$ eye drop is more beneficial for seasonal allergic conjunctivitis

Benefit of study in future- This is the one of unique study in terms of that we used combination of olopatadine and ketorolac in treatment of allergic conjunctivitis which have better efficacy and results rather than single drug so it will be beneficial in future for patients as well as doctor

\section{References}

1. Castillo M, Scott NW, Mustafa MZ, Mustafa MS, Azuara-Blanco A. Topical antihistamines and mast cell stabilisers for treating seasonal and perennial allergic conjunctivitis. Cochrane Database Syst Rev. 2015 Jun 1;(6):CD009566. doi: 10.1002/14651858.CD009566.pub2.

2. Liu R, Wu X, Wang X, Gao J, Zhou J, Zhao Q. Efficacy of olopatadine hydrochloride $0.1 \%$, emedastine difumarate $0.05 \%$, and loteprednol etabonate $0.5 \%$ for Chinese children with seasonal allergic conjunctivitis: a randomized vehiclecontrolled study. Int Forum Allergy Rhinol. 2017;7:393-398.

3. Uchio E. Treatment of allergic conjunctivitis with olopatadine hydrochloride eye drops. Clin Ophthalmol. 2008 Sep;2(3):525-31.
4. Yaylali V, Demirlenk I, Tatlipinar S, Ozbay D, Esme A, Yildirim C, Ozden S. Comparative study of $0.1 \%$ olopatadine hydrochloride and $0.5 \%$ ketorolac tromethamine in the treatment of seasonal allergic conjunctivitis. Acta Ophthalmol Scand. 2003 Aug;81(4):378-82.

5. Abelson MB, Schaefer K. Conjunctivitis of allergic origin: immunologic mechanisms and current approaches to therapy. Surv Ophthalmol. 1993 Jul-Aug;38 Suppl:115-32.

6. Mehmet Borazan,1 Aylin Karalezli,1 Yonca Aydin Akova etal. Efficacy of olopatadine HCI $0.1 \%$, ketotifen fumarate $0.025 \%$, epinastine HCI $0.05 \%$, emedastine $0.05 \%$ and fluorometholone acetate $0.1 \%$ ophthalmic solutions for seasonal allergic conjunctivitis: a placebo controlled environmental trial. Acta Ophthalmol. 2009: 87: $549-554$.

7. Bonini S. The early and late phases of the ocular allergic reaction. Presented at the Second International Symposium. Challenges, Strategies and Tools to Optimize the Management of Ocular Allergy 22-25 June 1999, Leeds Castle, Kent,UK.

8. Aguilar AJ. Comparative study of clinical efficacy and tolerance in seasonal allergic conjunctivitis management with $0.1 \%$ olopatadine hydrochloride versus $0.05 \%$ ketotifen fumarate. Acta Ophthalmol Scand Suppl. 2000; (230): 52-5.

9. Bielory L. Update on ocular allergy treatment. Expert Opin Pharmacother. 2002 May; 3 (5): 541-53.

10. Bonini S, Gramiccioni C, Bonini M, Bresciani M. Practical approach to diagnosis and treatment of ocular allergy: a 1-year systematic review. Curr Opin Allergy Clin Immunol. 2007 Oct; 7(5):446-9.

11. Hong, J. et al. Ambient air pollution, weather changes, and outpatient visits for allergic conjunctivitis: A retrospective registry study. Sci. Rep. 6, 23858; doi: 10.1038/srep23858 (2016).

12. Berdy GJ, Abelson MB, George MA, Smith LM, Giovanoni RL. Allergic conjunctivitis: a survey of new antihistamines. J Ocul Pharmacol. 1991 Winter;7(4):313-24. 
13. Leonardi A, Zafirakis P. Efficacy and comfort of olopatadine versus ketotifen ophthalmic solutions: a double-masked, environmental study of patient preference. Curr Med Res Opin. 2004 Aug; 20 (8):1167-73.

14. Irani AM, Butrus SI, Tabbara KF, Schwartz LB. Human conjunctival mast cells: distribution of MCT and MCTC in vernal conjunctivitis and giant papillary conjunctivitis. J Allergy Clin Immunol. 1990 Jul; 86(1):34-40.

15. Verin P, Easty DL, Secchi A, Ciprandi G, Partouche P, Nemeth-Wasmer G, Brancato R, Harrisberg CJ, Estivin-Ebrardt C, Coster DJ, Apel AJ, Coroneo MT, Knorr M, Carmichael TR, KentSmith BT, Abrantes P, Leonardi A, Cerqueti PM, Modorati G, Martinez M. Clinical evaluation of twice-daily emedastine $0.05 \%$ eye drops (Emadine eye drops) versus levocabastine $0.05 \%$ eye drops in patients with allergic conjunctivitis. Am J Ophthalmol. 2001 Jun;131(6):691-8.

16. Torkildsen G. Effective ocular allergy treatments are dual action. Ophthalmology Times, 1 April (2006).

17. Avunduk AM, Tekelioglu Y, Turk A, Akyol N. Comparison of the effects of ketotifen fumarate $0.025 \%$ and olopatadine $\mathrm{HCl} 0.1 \%$ ophthalmic solutions in seasonal allergic conjunctivitis:a 30-day, randomized, double-masked artificial tear substitute-controlled trial. Clin Ther. 27(9), 13921402 (2005).

18. Kurt RA, Ucakhan-Gunduz M, Gunduz K.Olopatadine $0.1 \%$ and $0.2 \%$ ophthalmic solution for the management of ocular allergy Expert Rev. Opthamol.2010; 5(3), 287-296.

19. Abelson MB \& Spitalny L. Combined analysis of two studies using the conjunctival allergen challenge model to evaluate olopatadine, a new ophthalmic antiallergic agent with dual activity. AmJ Ophthalmol 1998, 125: 797-804.

20. Deschenes J, Discepola M, Abelson M. Comparative evaluation of olopatadine ophthalmic solution $(0.1 \%)$ versus ketorolac ophthalmic solution $(0.5 \%)$ using the provocative antigen challenge model. Acta Ophthalmol Scand Suppl. 1999;(228):47-52.
21. Sharif NA, Xu SX, Miller ST, Gamache DA \& Yanni JM. Characterization of theocular antiallergic and antihistaminic effects of olopatadine (AL-4943A), a novel drug for treating ocular allergic diseases. J Pharmacol Exp Ther 1996, 278: 1252-1261.

22. Yanni JM, Stephens DJ, Miller ST, Weimer LK, Graff G, Parnell D, Lang LS, Spellman JM, Brady MT, Gamache DA. The in vitro and in vivo ocular pharmacology of olopatadine (AL-4943A), an effective anti-allergic/antihistaminic agent. J Ocul Pharmacol Ther. 1996 Winter; 12 (4): 389-400.

23. Wong AH, Barg SS, Leung AK. Seasonal and perennial allergic conjunctivitis. Recent Pat Inflamm Allergy Drug Discov. 2009 Jun; 3(2): 118-27.

24. Ostler HB: Vernal conjunctivitis. In Diseases of the external eye and adnexae: a text and atlas. 1st ed. Edited by Ostler HB. Baltimore: Williams \& Wilkins; 1993:125.

25. Pavlos Michailopoulos,Dimitrios Gioulekas, Paschalina Giouleka etal Allergic conjunctivitis and the most common allergens in Northern GreeceWorld Aller Organ J. 2013; 6(1): 12 doi: 10.1186/1939-4551-6-12

26. Leonardi A, De Dominicis C, Motterle L: Immunopathogenesis of ocular allergy: a schematic approach to different clinical entities. Curr Opin Allergy Clin Immunol 2007, 7(5):429-435.

27. Leonardi A: The central role of conjunctival mast cells in the pathogenesis of ocular allergy. Curr Allergy Asthma Rep 2002, 2(4): 325-331.

28. Leonardi S, Marchese G, Marseglia GL, La Rosa M: Montelukast in allergic diseases beyond asthma. Allergy Asthma Proc 2007, 28(3):287-291. 37. Abelson MB, Paradis A, George MA, Smith LM, Maguire L, Burns R: Effects of

29. Abelson MB, Paradis A, George MA, Smith LM, Maguire L, Burns R. Effects of Vasocon-A in the allergen challenge model of acute allergic conjunctivitis. Arch Ophthalmol. 1990 Apr;108 (4): 520-4. 
30. Mishra GP, Tamboli V, Jawla J, Mitra AK: Recent patents and emerging therapeutics in the treatment of allergic conjunctivitis. Inflamm Allergy Drug Discov 2011, 5:26-36

31. Kari O, Saari KM. Updates in the treatment of ocular allergies. J Asthma Allergy. 2010 Nov 24;3 : 149-58. doi: 10.2147/JAA.S13705.

32. Spector SL, Raizman MB. Conjunctivitis medicamentosa. J Allergy Clin Immunol. 1994 Jul; 94 (1):134-6.

33. Dell SJ, Shulman DG, Lowry GM, Howes J: A controlled evaluation of the efficacy and safety of loteprednol etabonate in the prophylactic treatment of seasonal allergic conjunctivitis. Loteprednol Allergic Conjunctivitis Study Group. Am J Ophthalmol 1997, 123:791-797.

34. Dell SJ, Lowry GM, Northcutt JA, Howes J, Novack GD, Hart K: A randomized, doublemasked, placebo-controlled parallel study of $0.2 \%$ loteprednol etabonate in patients with seasonal allergic conjunctivitis. J Allergy Clin Immunol 1998, 102:251-255.

35. Fan DS, Yu CB, Chiu TY, Wong CY, Ng JS, Pang CP, Lam DS. Ocular-hypertensive and antiinflammatory response to rimexolone therapy in children. Arch Ophthalmol. 2003 Dec; 121 (12): 1716-21

36. Pflugfelder SC, Maskin SL, Anderson B, Chodosh J, Holland EJ, De Paiva CS,Bartels SP, Micuda T, Proskin HM, Vogel R: A randomized, double-masked, placebo-controlled, multicenter comparison of loteprednol etabonate ophthalmic suspension, $0.5 \%$, and placebo for treatment of keratoconjunctivitis sicca in patients with delayed tear clearance. Am J Ophthalmol 2004, 138: 444-457.

37. Comstock TL, Decory HH: Advances in corticosteroid therapy for ocular inflammation: loteprednol etabonate. Int J Inflam 2012. Epub 2012 Mar 28.

38. Maziak W, Behrens T, Brasky TM, Duhme H, Rzehak P, Weiland SK, Keil U: Are asthma and allergies in children and adolescents increasing.
Results from ISAAC phase I and phase III surveys in Munster, Germany. Allergy 2003, 58:572-579.

39. Volkan Yaylali, Ibrahim Demirlenk, Sinan Tatlipinar etal Comparative study of $0.1 \%$ olopatadine hydrochloride and $0.5 \%$ ketorolac tromethamine in the treatment of seasonal allergic conjunctivitis Acta Ophthalmol. Scand. 2003: 81: $378-382$

40. Pallasaho P, Ronmark E, Haahtaela T, Sovijarvi ARA, Lundback B. Degree and clinical relevance of sensitization to common allergens among adults: a population study in Helsinki, Finland. Clin Exp Allergy. 2006;6:503-509. doi: 10.1111/j.13652222.2006.02460.x. [PubMed] [Cross Ref]

41. Raukas-Kivioja A, Raukas E, Loit HM, Kiviloogt J, Ronmmark E, Larssons K, Lundback B. Allergic sensitization among adults in Tallinn, Estonia. Clin Exp Allergy. 2003;6:1342-1348. doi: 10.1046/j. 1365-2222. 2003.01774.x. [PubMed] [Cross Ref]]

42. Katelaris $\mathrm{CH}$, Ciprandi G, Missotten L; International Olopatadine Study Group. 2002. A comparison of the effi cacy and tolerability of olopatadine hydrochloride $0.1 \%$ ophthalmic solution and cromolyn sodium $2 \%$ ophthalmic solution in seasonal allergic conjunctivitis. Clin Ther, 24:1561-75.

43. Tinkelman DG, Rupp G, Kaufman H, Pugely J, Schultz N. Double-masked, paired-comparison clinical study of ketorolac tromethamine $0.5 \%$ ophthalmic solution compared with placebo eyedrops in the treatment of seasonal allergic conjunctivitis. Surv Ophthalmol. 1993 Jul-Aug;38 Suppl:133-40.

44. Sarker Chowdhury, Hussain, Hossain \& ChowdhuryComparison of the therapeutic efficacy of $0.1 \%$ olopatadine hydrochloride and $0.025 \%$ ketotifen fumarate in allergic conjunctivitisTherapy 2011; 8(5), 545-553

45. Mortemousque B, Bourcier T, Khairallah M, Messaoud R, Brignole-Baudouin F, Renault D, Rebika H, Brémond-Gignac D; Ketotifen Study Group. Comparison of preservative-free ketotifen fumarate and preserved olopatadine hydrochloride eye drops in the treatment of moderate to severe 
seasonal allergic conjunctivitis. J Fr Ophtalmol. 2014 Jan;37(1):1-8. doi: 10.1016/j.jfo.2013.02.007. Epub 2013 Dec 31.

46 Donshik PC, Pearlman D, Pinnas J, Raizman MB, Tauber J, Tinkelman D, Walters TR. Efficacy and safety of ketorolac tromethamine $0.5 \%$ and levocabastine $0.05 \%$ : a multicenter comparison in patients with seasonal allergic conjunctivitis. Adv Ther.2000 Mar-Apr; 17(2): 94-102.

47. Deschenes J, Discepola M, Abelson M. Comparative evaluation of olopatadine ophthalmic solution $(0.1 \%)$ versus ketorolac ophthalmic solution $(0.5 \%)$ using the provocative antigen challenge model.Acta Ophthalmol Scand Suppl. 1999; (228):47-5228

48. Spangler DL, Bensch G, Berdy GJ. Evaluation of the efficacy of olopatadine hydrochloride $0.1 \%$ ophthalmic solution and azelastine hydrochloride $0.05 \%$ ophthalmic solution in the conjunctival allergen challenge model. Clin Ther. 2001 Aug; 23(8):1272-80.
49. Lanier BQ, Finegold I, D'Arienzo P, Granet D, Epstein AB, Ledgerwood GL. Clinical efficacy of olopatadine vs epinastine ophthalmic solution in the conjunctival allergen challenge model. Curr Med Res Opin. 2004 Aug; 20(8): 1227-33.

50. McLaurin E, Narvekar A, Gomes P, Adewale A, Torkildsen G.Phase 3 Randomized DoubleMasked Study of Efficacy and Safety of OnceDaily $\quad 0.77 \% \quad$ Olopatadine Hydrochloride Ophthalmic Solution in Subjects With Allergic Conjunctivitis Using the Conjunctival Allergen Challenge Model.Cornea. 2015 Oct;34(10): 124551. doi: 10. 1097/ ICO. 0000000000000 562.

51. Mah FS, Rosenwasser LJ, Townsend WD, Greiner JV, Bensch G. Efficacy and comfort of olopatadine $0.2 \%$ versus epinastine $0.05 \%$ ophthalmic solution for treating itching and redness induced by conjunctival allergen challenge. Curr Med Res Opin. 2007 Jun;23(6):1445-52. Epub 2007 May 18.

\section{How to cite this article?}

Meena R.K, Gupta M.L, Sharma H.P. A comparative study of Olopatadine and Ketorolac eye drop with Ketorolac eye drop alone in seasonal allergic conjunctivitis. Int J Med Res Rev 2017;5(09):829838.doi:10.17511/ijmrr. 2017.i09.01. 